\section{ASSESSMENT OF HIGH SCHOOL PRINCIPAL'S TRANSFORMATIONAL LEADERSHIP}

\author{
Nahiyah Jaidi Faraz \\ Management Departement of Yogyakarta State University \\ e-mail: Nahiya_jf@yahoo.com
}

\begin{abstract}
This study aimed to identify the construct of school principal's transformational leadership, and to find assessment of school principals transformational leadership. The research location was senior high schools in Yogyakarta Special Territory. A sample of 18 schools was determined making use of proportionate random sampling technique. There were 360 female and male teachers of all study programs as the source of the data. The results of the study show the following: First, the construct of the school principal's transformational leadership theoretically hypothesized fits the empirical data as indicated by all high and significant factors, and a relatively high coefficient of determinant. Second, the school principal's transformational leadership, based on the teacher assessment fits the hypothesized as indicated high, and significant points in all indicators and a relatively high determinant coefficient .
\end{abstract}

Keywords: assessment, transformational leadership, principal, teacher.

\begin{abstract}
Abstrak
Penelitian ini bertujuan untuk mengidentifikasi konstruk kepemimpinan transformasional kepala sekolah, mengetahui kepemimpinan transformasional kepala sekolah berdasarkan asesmen guru hubungannya dengan kinerja sekolah, memperoleh model asesmen kepemimpinan transformasional kepala sekolah oleh guru, dan mengetahui besarnya perbedaan kepemimpinan transformasional kepala sekolah menengah atas negeri dan swasta berdasarkan asesmen guru. Tempat uji model adalah Sekolah Menengah Atas (SMA) Negeri dan Swasta di DIY. Besarnya sampel 18 dengan proportionate random sampling. Diasumsikan setiap SMA negeri maupun swasta diwakili 20 orang guru sehingga diperoleh sumber data 360 guru. Hasil penelitian ini menunjukkan bahwa: Pertama, konstruk kepemimpinan transforma sional kepala sekolah yang dihipotesiskan cocok (fit) dengan data empiris, yang didukung semua indikator, dan koefisien determinan yang signifikan. Kedua, model asesmen kepemimpinan transformasional kepala sekolah oleh guru cocok (fit) dengan model yang dihipotesiskan, didukung muatan faktor, dengan semua indikator dan koefisien determinan yang signifikan.
\end{abstract}

Kata kunci: asesmen, kepemimpinan transformasional, kepala sekolah, guru.

\section{INTRODUCTION}

There are limited numbers of empirical studies on high school principal' leadership as well as on assessment as efforts to increase empirically good leadership as the foundation to the principal's quality progress. Sudrajat (2010) states that school principal selections are more seniority and higher rank-based, rather than leadership qualification consideration - based. In many cases, school principals' selection are based on intervention of higher authorities so that competence and professionalism standard are neglected.

The illustration above is not supporting at all to the progress and development of education in Indonesia. Due one of the keys in education is the school, and the centralized character is the principal, school performance can be identically related to the principal's performance (Xaviery, 2004). The focus of princi- 
pal's role analysis would be the role as a manager who is responsible for distributing roles of members of organization in order to keep the organization effective.

From various studies, the outstanding one advances the idea that school principal should be able to influence other members of the school to reach the goal set by the school. The skill to influence is what scholars call as transformational leadership. Hence, many school principals apply the leadership style although they do not know what is the name of the style they perform (Sudrajat, 2009).

Briefly, transformational leadership is a process to change and transform individuals and groups to improve themselves in terms of motivation, need fulfilment, and respect to staffs. Bass and Avolio (1994) define transformational leadership to include idealized influence, inspirational motivation, intellectual stimulation, and individualized consideration, what is commonly called the Four Is. Idealized influence can be meant that school principals are the ideal for other school members like teachers, students, and administration staffs. Inspirational motivation is that school principals can motivate other school members to be committed with the school's vision and mission. Intellectual Stimulation is meant that school principals are able to stimulate creativity, innovation, and critical thinking of school members. Last, individual consideration is when school principals can act as trainers, teachers, as well as advisor to other school members.

Review of literature by Northouse (2007) summarizes that those who can perform transformational leadership can be considered as effective leader with better performance. Therefore, it is very beneficial to school principals who apply transformational leadership. Burns (1976) states that hypotheses transformational leadership happens only when school principals and other school members are in a unity to gain the same goal that is to succeed school's mission and objectives.

Results of the research on leadership in business, industry, governance, military, and educational and non-profit institutions show that transformational leadership is more effective applied than the transactional (Shamir, House and Arthur, 1993). A research by Koh, Steers and Terborg (1995) involving 846 teach- ers and school principals in 89 junior high schools in Singapore shows that organizational commitment, members' attitude, and work satisfaction is high when the teachers portray their MLQ scale based transformational principals (Bass and Reggio, 2006).

Transformational leadership in education world can be meant as efforts of school principals to motivate teachers and administration staffs to consistently gain the mission set by the school. This transformational leadership are practiced in many institutions in Indonesia, including those which are in Yogyakarta Special Territory. In the world of education, however, is still an on going process heading on to the ideal one. Further studies especially on the best practice of the leadership need to be implemented. Therefore, this study empirically seeks effectiveness of transformational leadership through assessing teachers as the subordinate assessment.

Teachers' assessment can maintain effectiveness of transformational leadership. Therefore, teachers assessment is used in further analysis of effectiveness and hospitalization of the practices of the transformational leadership. The bottom up assessment used aims to develop human resources in academic supervision using non directive approach.

Subordinate Assessment includes performance assessment, which supposedly effective enough to increase qualification of transformational leadership of the school principals. However, due only few with increasing result (Ilgen, Fisher and Taylor, 1979), the needs to be empirically assesed. Indirectly, the assessment done indicates loyalty, responsibility, and actual participation of the teachers in school activities (Bass and Reggio, 2006). For the sake of internal validation, on the effectiveness of the assessment, the link between outcome (accreditation) and output (Result of national examination) and the difference of the leadership in state and private schools need to study.

The results of the study using subordinate assessment instrument to identify subordinate factors like what have been done by Dayton-Montgomery County (Ohio, 2002) Show that the subordinates assess supervisors high as models. The subordinates also hope that the supervisors would treat them well, appreciate their opinions, and help them deal with their weaknesses (Rubin, 2002). 
Based on previous background and empirical researches, the formulation of the problems in this study are the following: How is the construct of transformational leadership of the school principals? How does teachers assessment-based transformational leadership of the school principal relate to school performance? How is the assessment of school principal's transformational leadership conducted by teachers? and how much different is the transformational leadership of state and private school principals?

The objectives of this research was to identify construct of school principal's transformational leadership, to understand teachers assessment-based transformational leadership of the school principal and its relation to school performance, to gain teachers based assessment of school principal's transformational leadership, to know the difference between transformational leadership of state school principals and private school principals.

\section{LITERATURE REVIEW}

Transformational leadership is one approach to leadership that is currently often the focus of research since the early 1980's, This approach is a part of the paradigm of "New Leadership" (Bryman, 1992). As the name suggests, transformational approach is a process that changes and transforms individuals. This approach relates to the values, ethics, standards, and longterm goals.

Komariah and Triatna (2008) mention that transformational leadership can be seen in the micro and macro. On the micro level transformational leadership is a process of influence between individuals, while the macro is the process of mobilizing power to change social systems and institutional reform. Northouse (2007) states that transformational leadership is a mutually reinforcing process between leaders and followers to the level of morality and motivation higher. Transformational leadership is not only direct and top-down (from top to bottom), but also can be observed indirectly, from bottom to top (Bottom up), and horizontally.

Sosik, Godshalk and Yammarino (2004) state that the core element of transformational leadership is the development of followers or subordinates to enhance their capability and capacity in the lead. Sosik et al notes the similarity between transformational leadership and the effectiveness of coaching. Furthermore Northouse (2007) provides several ways to implement transformational leadership, namely as follows: 1) Empower all members of the organization to do the best for the organization; 2) Trying to be a leader who can be imitated based on high value Listen to all thinking members of the organization to develop a spirit of cooperation; 3) Create a vision that can be believed by all the members of the organization Acting as an agent of change in organizations by providing examples of how to conceive and implement a change; 4) Helping organizations by helping others to contribute to the organization.

Research conducted Barnett, Marsh and Craven (1995) in 52 secondary schools in Australia showed that the principal's transformational leadership style is relatively more reliable than the transactional style and Laissez Faire in manipulating their environment to achieve organizational goals or reach the school. Similarly, a research conducted Bartling and Bartlett (2005) suggests that transformational leadership is greater than 3.27 on average 1.95 transactional leadership which is then greater than the average of laissez-faire leadership 0.79 .

A research by Koh, Steers and Terborg (1995) involving 846 teachers and school principals in 89 junior high schools in Singapore shows that organizational commitment, members' attitude, and work satisfaction is high when the teachers portray their MLQ scale based transformational principals (Bass and Reggio, 2006). This means that the higher leadership of schools rated as transformational leaders by the teacher, the lower the tendency of teachers to truant, receiving unnecessary phone, etc. are all positively linked to the rejection of active and passive management by exception. There is no significant relationship of contingent reward. Similarly, Kelloway and Barling (1998) suggest that followers of transformational leadership assessment indicates teacher loyalty, sense of responsibility that will maintain teachers' job satisfaction and organizational commitment as well as actual participation in the activity of school organization.

The main advantage of subordinates or followers who assess the leadership, namely: First, the situation of the leadership and subor- 
dinate relationships are important, assessment of subordinates can be useful in identifying competent leadership. Secondly, this type of program can help leaders to be more responsive to their subordinates, although this advantage can quickly become a liability if it ultimately led just trying to be good and instead manage subordinates. Third, assessment of subordinates can be the basis for coaching as part of their managerial development (Mathis and Jackson, 2002).

Research from Barnett (2004) conducted in New South Wales State secondary school explained that the variation of data is usually contained in the findings from the teacher at the school level. This indicates the relationships that exist between the principal as a leader and teacher as a follower, of the principal with a group of followers. Therefore, individualised consideration factor in transformational leadership has a greater impact on teacher assessment, perception, and satisfaction with the leadership than the idealized influence factor. Furthermore, Barnett (2004) states that resource teachers have access to a wide range of individuals, information, and material resources so that they can change the behaviour of school principals by using different strategies.

Persisco (2001) also conducted a research on the relationship between teacher assessments against the principal who has high transformational leadership style development with the practice of professional teachers. The results show that there was a positive and significant relationship between transformational constructs such as idealized influence (behaviour), inspirational motivation, and individualized consideration. Then, there was no significant relationship between transformational constructs such as intellectual stimulation, and the quality of leadership. This means that transformational constructs received by the teacher will inspire commitment to the organization.

The results from Pidekso, Agung and Harsiwi (2001) demonstrate that subordinate ratings of transformational leadership with personal characteristics of leaders at the University of Atma Jaya Yogyakarta was not significant relationship. While the assessment of subordinates on all dimensions of transformational leadership that is idealized influence, inspirational motivation, intellectual stimulation, indi- vidualized consideration, shows a very strong relationship and in the same direction as the personal characteristics of the educational level of the leader.

Based on the above description, each researcher has evidence and argument so that each can be understood that the assessments of teachers on transformational leadership in several countries including Indonesia vary. The partial results oft the research on teacher assessment on principal transformational leadership to all the factors and some factors such as individualised consideration indicate a strong influence on the principal leadership in career development and attitudes and behavior of the teachers themselves in both public and private high school.

\section{RESEARCH METHOD}

The design of this research is an ex-post facto, studying variables of teachers assessment toward school principal's transformational leadership without direct manipulation by the researcher (Isaac and Michael,1983) The criteria approach used is preordination, deciding criteria before the research is executed (Hasan,1988). Teachers asses school principal's transformational leadership is the subordinate assessment which also constitutes performance assessment especially on the contextual performance that supports core jobs of organization in a larger community (Reio,1997). The schools tested are state and private senior high schools in Yogyakarta totalling 172 schools with 5873 teachers as data source (Dinas Pendidikan Propinsi DIY,2007/2008). Cochran (1997) determines the number of sample that are 18 state and private schools. Assuming that each school has 20 teachers, the data source is 360 male and female teachers from various disciplines. Proportionate random sampling (Winarsunu,2002) is used to determine the schools and random sampling to determine the teachers.

Questionnaires instrument used to collect the data is the Multifactor Leadership Questionnaire (MLQ). MLQ consists of four factors namely exemplary, inspirational motivation, intellectual stimulation and individualized consideration (Bass and Avolio, 1995). That is to measure transformational leadership of the principals in secondary school principals 
via public and private teacher (subordinate ratings) and developed and adapted according to the Indonesian culture, and measured by the Likert Scale. Exemplary dimensions are measured by the principal items to keep the implementation of school programs that have been planned with the teachers. Inspirational motivation dimensions are measured by the principal explained the importance of the item using the program or the new method that is more effective in carrying out school assignments. Dimension of intellectual stimulation as measured by principal item in resolving the problem is always a way deliberation to reach an objective decision. Individual consideration dimension is measured by joining the appropriate training to their expertise.

A modified key performance indicator was to collect data on school's performance, the outcome and the output. Documentation completed the data collection on the schools' performance. Data were analyzed using the following techniques: 1). First- order confirmatory factor analysis, to test variable construct or the single dimensional sub-variable. 2). Rank order correlation by Spearman (Furlong, Lovelace and Lovelace, 2000) to measure correlation of the two ordinal data variables. 3). Second - order confirmatory factor analysis (Jore- skog and Sorbom,2003) to test plural dimensional variable construct. 4). MANOVA, to measure the teacher's assessment-based difference of the school principals' transformational leadership.

\section{FINDINGS AND DISCUSSION}

\section{Measuring Construct of School Principals' Transformational Leadership}

Idealized influence (see figure 1), the indicator used are vision, mission, pride, reward, and trust. The result of the test using CFA is ChiSquare $=4.83>0.05$ p-value $=0.43675$ and RMSEA $=0.000<0.080$. This means that both shows hypotheses construct fitting with the empirical data /fit (Significant $\mathrm{p}<0.050$ )

Inspirational motivation (see figure 2), the indicators used consist of high expectation communication, terms usage, significant goal expression, and optimism increase. Second order confirmatory factor analysis testing motivation and inspiration construct shows ChiSquare $=5.97>0.05$ p-value $=0.05049$ and RMSEA $=0.074<0.080$. This means that both results show that the hypotheses construct fits with the empirical data (Significant $p<0.050$ )

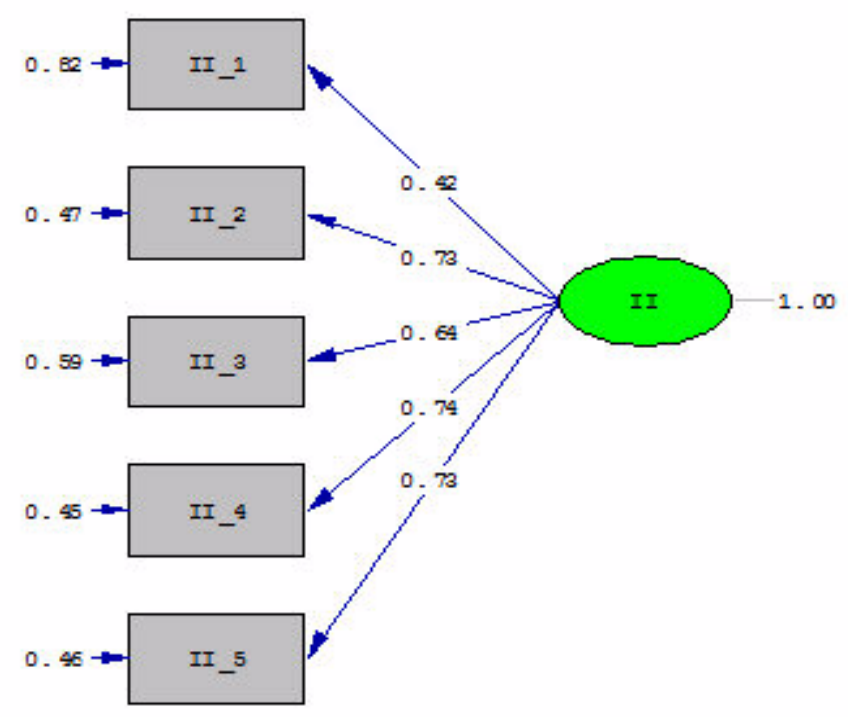

Chi-Square $=4.83, d f=5, P-$ value $=0.43675$, RMSEA $=0.000$

Figure 1. Result of Idealized Construct 


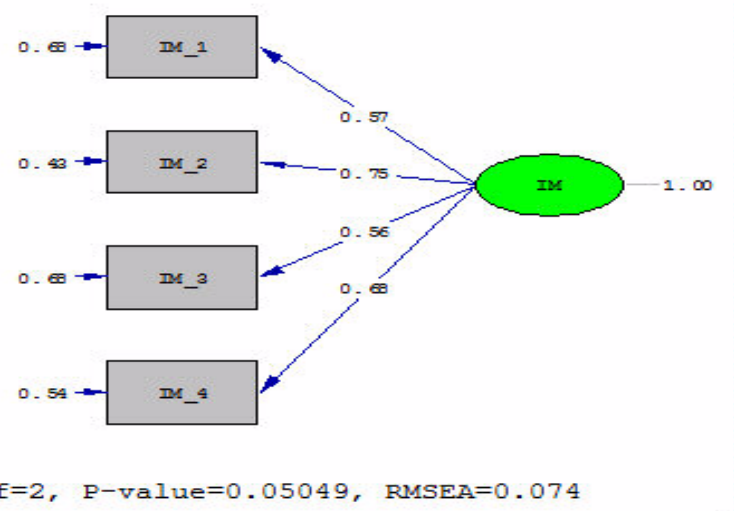

Figure 2. Result of Inspirational Motivation Construct

Intellectual stimulation (see figure 3), the indicators used consist of innovative support, new approach, and the art of rational problem solving. Analysis of confirmatory factor shows Chi-Square $=2.48>0.05$ p-value $=0.29010$ and RMSEA $=0.026<0.080$. That means that the hypotheses construct fits with the empirical data.
Individual consideration (see figure 4), the indicators used consist of individual attention, teachers treatment, training, and workshops. Analysis of confirmatory factor shows ChiSquare $=4.65>0.05 \quad \mathrm{p}$-value $=0.09759$ and RMSEA $=0.061<0.080$. This means that both results fit with the hypotheses construct (Significant $\mathrm{p}<0.050$ )

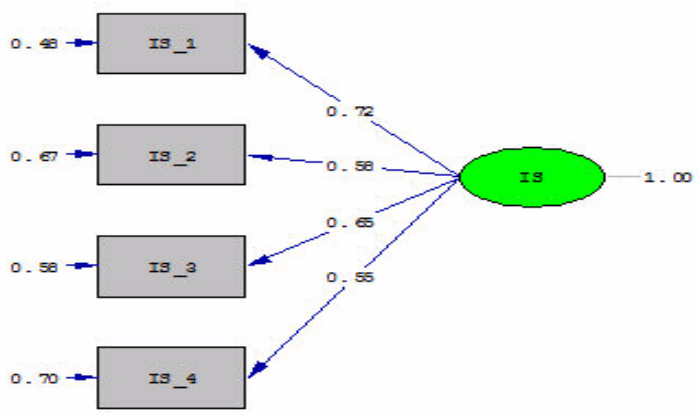

Chi-Square=2.48, df=2, P-value=0.29010, RMSEA=0.026

Figure 3. Result of Intellectual Simulation Construct

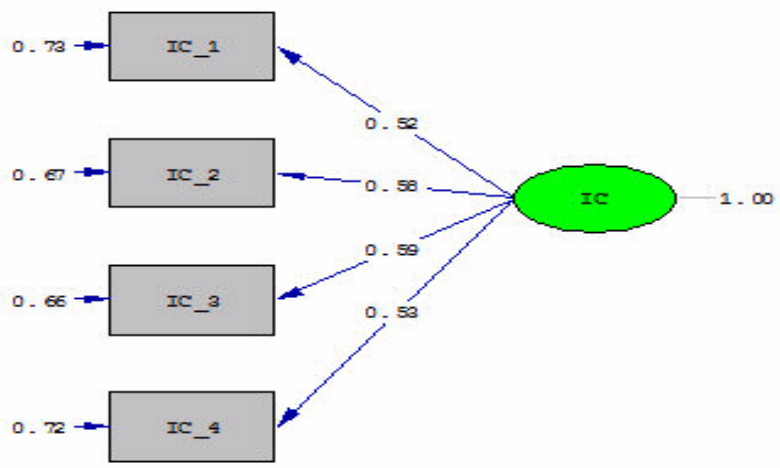

Chi-Square=4.65, df=2, P-value=0.09759, RMSEA=0.061

Figure 4. Result of Individual Consideration Construct 
The findings above are in line with what Bass and Avolio (1994) state that respect and trust, and understanding, high morality, challenging set of goals, and model for the follower mark the idealized factor. Motivation inspiration includes to inspire and present vision and mission clearly, confidence, optimism, group spirit, and enthusiasts. Factors of stimulation inspiration are marked by attitudes showing efforts of leader to make the followers more innovative and creative in asking assumptions, mapping problems, and approaching the followers in various new ways. Factors of individual consideration treats the followers by giving them attention, respect them, and trust them in executing tasks.

\section{Relation between Teachers' Assessment to School Principals' Transformational leader- ship and School Performance.}

Figure 5 shows that there is a significant relation between teacher's assessment on school principal leadership and result of national examinaton both in state and private schools, $(r=0.481$ with $\mathrm{p}=0.043)$. Good result of assessment to the practices of transformational leadership indirectly influences result of national examination. This result is in line with the result of meta analysis research by Janerette and Sherrretz (2007) finding positive correlation between responsibility of school principals and academic achievement of the students. Furthers, Bossert (Suskacevic and Blake, 1999) finds that school principals' attitude directly influences school atmosphere and structure of teaching and indirectly influences students' achievement. The chart above also shows that there is no significant relation between the assessment and the accreditation gained both in state and private high schools ( $\mathrm{r}=0.409$ with $\mathrm{p}=0.092$ ). Considering school accreditation as a technical administrative task to fulfil eight national standards, the execution of the task is a team work between school principal, teachers, and staffs. School principals is not only responsible, but should be directly involved. This situation affects teachers' assessment to the school principals' leadership. This result is in line with Meine (2010) stating that the recent accreditation should include eight national standard, and not only a single work of a school principal.

\section{Result of Assessment on School Principal's Transformational Leadership}

The measurement of assessment (Figure 6) shows Chi- Square $=139.57>0.05, \mathrm{CFI}=0.98$ $>0.95$ and $\mathrm{RMSEA}=0.024<0.080$. The three results, Chi-Square, CFI and RMSEA show that between the theoretical and hypotheses fits with gained from empirical data. The result is supported by factor load and all high and significant indicators $(>0.40), \quad(p<0.050)$. The highest determinant coefficient is $54 \%$ and the lowest one is $18 \%$, each constituting the reward and trust indicators (II_4 \& II_5) toward idealized factor and vision statement ( II_1). The highest determinant coefficient from subvariables to the variable of transformational leadership is $70 \%$ owned by sub-variable motivation inspiration. And the lowest one is $19 \%$ in individual consideration. The result above will improve the performance of the school principals. That can also be used as to increase managerial effectiveness which is in line with the findings of Hegarty (1994) stating that effective subordinates can change in managerial attitudes. Besides, Velser, Ruderman and Phillip (1999) find that some leaders increase their performance after they get assessment from the followers (Atwater et al., 2005).

Result of Analysis of difference between teachers' assessment based transformational leadership and the Wilks'Lambda formula shows that school status gains $\mathrm{F} 10,747$ with $\mathrm{p}=0.000<0.05$. Therefore, I can be concluded that there is significant difference in the transformational leadership of the state and private school principals. On school status, the difference for idealized factor is F 26.060 with $\mathrm{p}<0.05$; intellectual stimulation is $\mathrm{F} 24.996$ with $\mathrm{p}<0.05$ ); and individual consideration factor is $\mathrm{F} 10.173$ with $\mathrm{p}<0.05)$. On motivation inspiration factor, $F$ is 0.542 with $p<0.05$ ). The difference shows that state schools are better in human resources and principal's, teaching and learning process, and networking. Such schools influence teachers in assessing school principal's transformation leadership. 


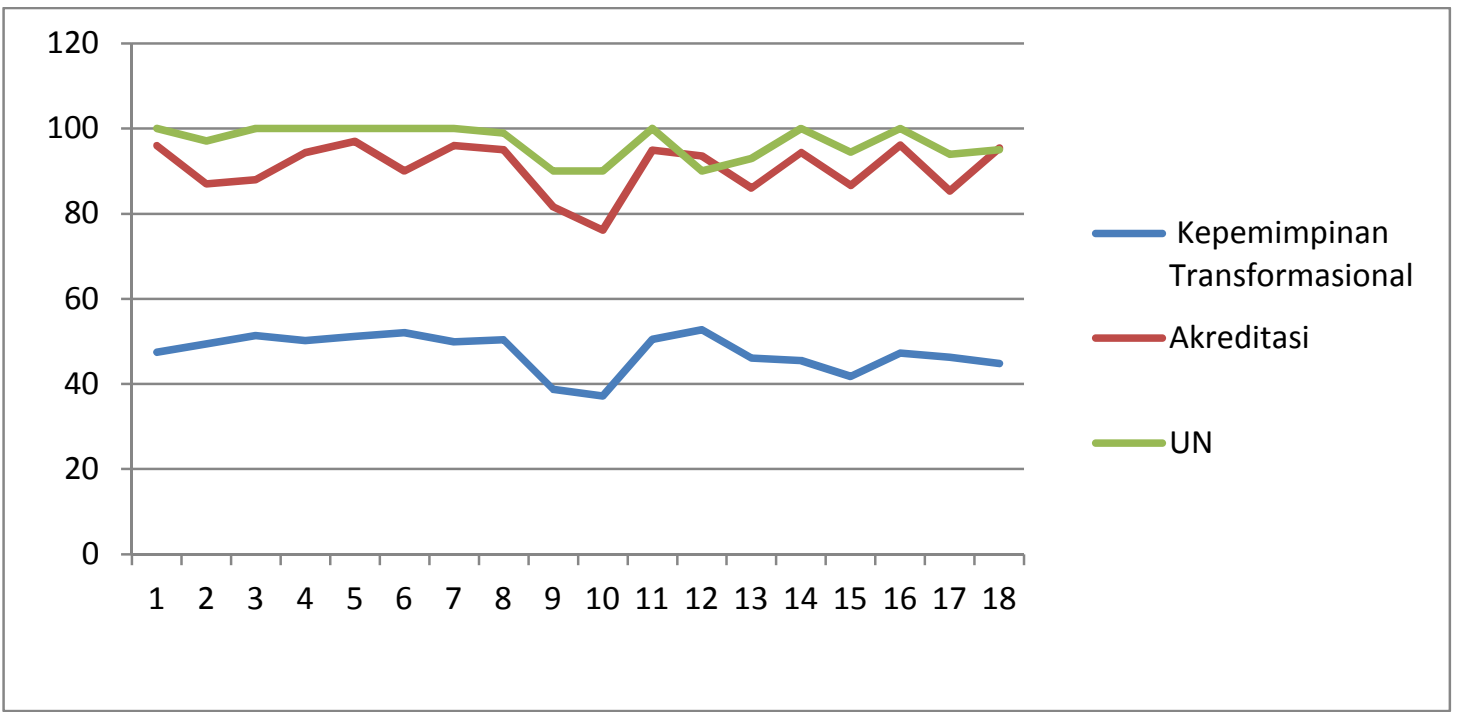

Figure 5: Relation between Teachers' Assessment to School Principals' Transformational leadership and School Performance.

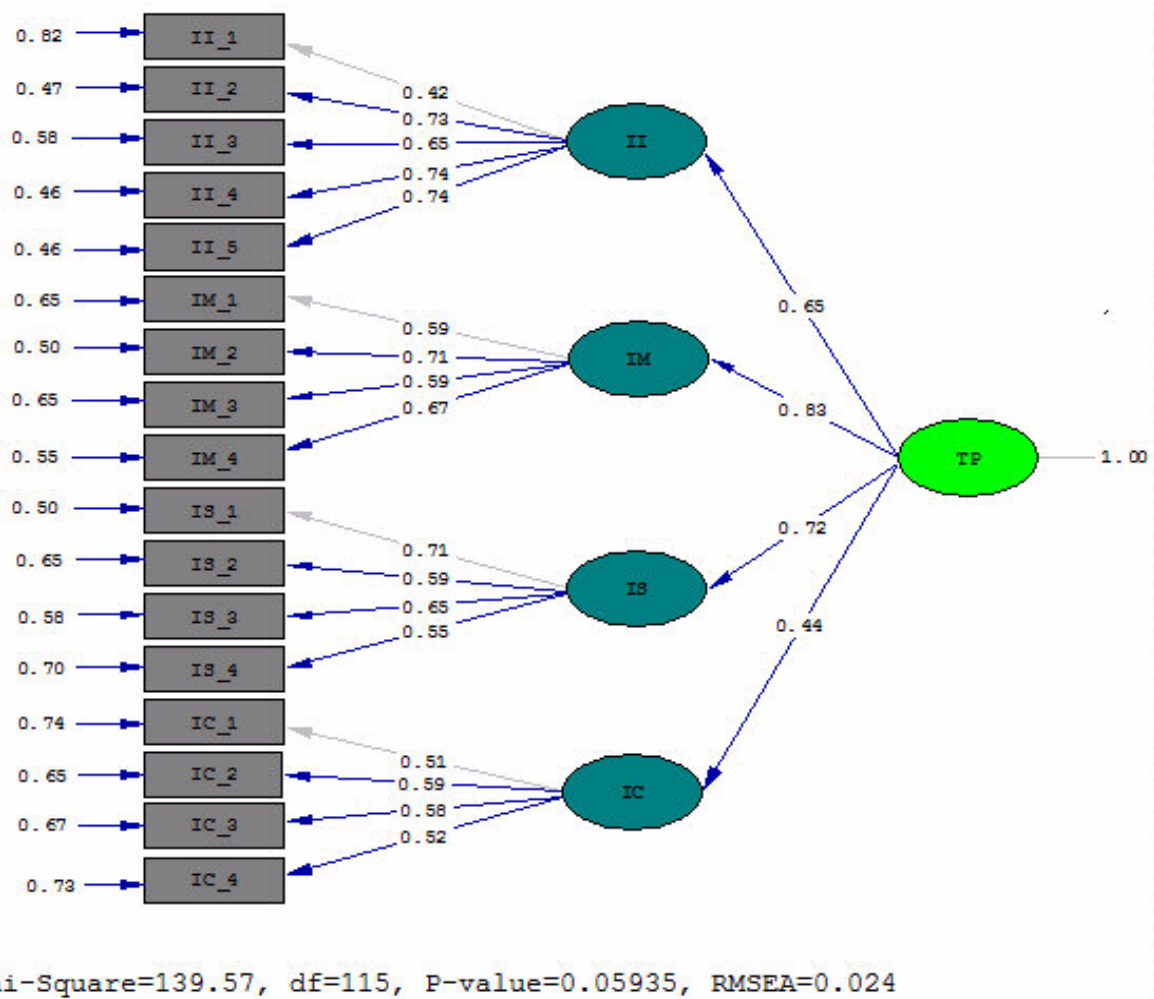

Figure 6. Result of Measurement

\section{CONCLUSION}

Construct of transformational leadership consists of idealized influence, inspirational motivation, intellectual stimulation, and individual consideration. All indicators show high and significant result $(>0.40),(\mathrm{p}<0.05)$. There is a significant relation between teacher's assessment based school principal's transformational leadership and result of national examination both in state and private schools $(\mathrm{r}=0.481$ with $\mathrm{p}=0.043$ ). There is no significant relation between teacher's assessment based school prin- 
cipal's transformational leadership and result of school accreditation both in state and private schools ( $\mathrm{r}=0.409$ with $\mathrm{p}=0.092$ ).

The assessment of transformational leadership of school principal's can be called the Four Is consisting of Idealized Influence, Inspirational Motivation, Intellectual Stimulation, and Individualized Consideration. The seventeen indicators supported empirical data is significant $(p<0.050)$. The highest determinant coefficient is inspirational motivation $70 \%$ and individualized consideration 19\%. There is difference assessment of state and private school teachers to the transformational leadership of the school principals $(\mathrm{F}=10.747$ with $\mathrm{p}<0.05)$ and on the idealized factor, $\mathrm{F}$ is 26.060 with $\mathrm{p}<0.05$; intellectual stimulation, $\mathrm{F}$ is 24.996 with $\mathrm{p}<0.05$ and individualized consideration, $\mathrm{F}$ is 10.173 with $p<0.05$. For inspirational motivation, $F$ is 0.542 with $p>0.05$ and there is no different assessment between state and private school teachers.

\section{SUGGESTIONS}

It needs more research on transformational leadership construct that uses data from different respondents as the principal or the school committee and the use of approaches, instruments, and different analysis techniques with CFA.

Assessment of transformational leadership of upper secondary school principals is quite effective in increasing the principal transformational leadership, and indirectly affects the performance of teachers such as teacher commitment to school organization, and job satisfaction of teachers and student achievement such as in the UN (National Examination) and the UAS (school Final Exam), making it feasible to apply in high school.

The results of this study indicate that transformational leadership assessment by the school head teacher is effective, then the principal should be generated using standard instruments of this study particularly inspirational motivation dimension.

\section{REFERENCES}

Aiken, L.R. 1989. Personality assessment: Methods and practices, Kirkland: Hogrefe and Huber Publisher.
Atwater, L., P. Roush and A. Fischthal. 2005. The influence of upward feedback on self and follower ratin. Personnel Psychology. 48 (1). 35-59.

Barnett, B.G. 2004. Subordinate Teacher Power in School Organizations Author Source: Sociology of Education, 57 (1). 43-55.

Bass, B.M. 1985. Leadership and Performance Beyond Expectations, New York: The Free Press.

Bass, B.M and B.J. Avolio. 1994. Improving organizational effectiveness: through transformational leadership. London: SAGE Publications.

Bass, B.M and R.E. Riggio. 2006. Transformational leadership. New Jersey: LEA. Publisers Marwah.

Bryman, A.1992. Charisma and Leadership in Organizations. London: SAGE Publication.

Burns, J.M.1976. Leadership, Perennial, An imprint of Harper Collins Publishers. www. harpercollins.com.

Cochran,W.G.1977. Sampling techniques (terjemahan). Jakarta: Penerbit Universitas Indonesia.

Dinas Pendidikan Provinsi Daerah Istimewa Yogyakarta. 2007/2008. Data dan informasi pendidikan. Yogyakarta.

Furlong.N.E., E.A. Lovelace and K.L. Lovelace. 2000. Research Methods and Statistics. An Integrated Approach. London: Harcourt College Publishers.

Hair,J.F., RE. Anderson, R.T. Tatham and W.C. Black. 1998. Multivariate data analysis $\left(5^{\text {th }}\right.$ ed), London: Prentice-Hall International.

Hasan, 1988. Evaluasi kurikulum. Jakarta : DIKTI Departemen Pendidikan Nasional.

Hegarty,W.1994. Using subordinate ratings to elicit behavioral change in supervisors. Journal of Applied Psychology.59.764766. 
Ilgen,D., C. Fisher, M. Taylor. 1979. Consequences of individual feedback on behavior in organizations. Journal of Applied Psychology. 64 (4). 349-371.

Isaac, S. and W.B. Michael. 1983. Handbook in research and evaluation. San Diego: EDIT publishers.

Janerrette, D. and K. Sherretz. 2007. School Leadership and Student Achievement. Education Policy Brief. Retrieved on January 2012, from http://www.rdc.udel.edu/.

Joreskog, K.G. and D. Sorbom. 2003. Lisrel 8: User's reference guide. Chicago: Scientific Software International.

Koh,W.L., R.M. Steers and J.R.Terborg. 1995.The effects of transformational leadership on teacher attitudes and student performance in Singapore. Journal of Organizational Bihavior.16 (4). Diambil pada tanggal 9 Desember 2009 , http://www.jstor.org/stable/2488561.

Komariah, A. dan C. Triatna. 2008. Visionary Leadership menuju sekolah efektif. Cetakan ketiga, Jakarta: PT Bumi Aksara.

Kelloway,E.K., and J. Barling.1998. Members' Partcipation in local union activities: Measurement, prediction and replication. Journal of Applied Psychlogy. 78. 262-279

Leithwood,K., D. Jantzi and R. Steinbach. 1999. Changing leadership for changing times, Philadelphia: Open University Press Buckingham.

Mathis, R.L and J.H. Jackson. 2002. Manajemen sumber daya manusia. Jakarta: Penerbit Salemba Empat.

Meine, W. 2010.Peranan Kepala Sekolah Dalam Akreditasi Sekolah. Diakses pada tanggal 6 oktober 2010 dari Http://peranan-kepala-sekolah-dalamakreditasi.html.

Nitko, A.J. 2007. Educational assessment of student. New Jersey: Pearson Education Inc.
Northouse, P.G. 2007. Leadership: Theory and practice. London: SAGE Publications,

Nunally, J.C. 1978. Psykometric theory. New York: McGraw Hill Book Company.

Persisco.M. 2001. Exploring the relationship between the perceived leadership style of secondary principals and the professional development practices of their teachers. USA: The International Leadership association.

Pidekso,Y.S., T. Agung dan M. Harsiwi. 2001. Hubungan kepemimpinan transformasional dan karakteristik personal pemimpin, Jurnal Bisnis dan Ekonomi. PPS Univ Atma Jaya Yogyakarta. 5 (1).

Reio, T.G. 1997. Effects of curiosity on sociolization-related learning and job performance in adults. Dissertation. USA: Virginia Polytecnic Institute and State Universty.

Rubin, R. 2002. Penilaian atas: Apa yang bawahan anggap penting dalam mengevaluasi pengawas mereka? Abstrak Tersedia online 12 April 2002.

Shamir,B., R.J. House and M.B. Arthur. 1993.The motivational effects of charismatic leadership: A self-concept based theory. Organization Science, 4(4), 577-594.

Sosik,J.J., V.M. Godshalk and F.J.Yammarino. 2004.Transformational leadership,learning goal orientation and expectations for career success in mentorprotégé relationships: A Multiple levels of analysis perspective. The leadership Quarterly. 15.241-261.

Sudrajat, A.2009. Apakah guru bisa menjadi pekerjaan profesional yang sejatinya? Diunduh pada tanggal 2 Agustus 2009 dari akhmadsudrajat's blog. 1-3.

Sudrajat, A. 2010. Konsep penilaian kinerja kepala sekolah. Diambil5 Oktober 2010 , dari file:///G:/Kumpulan Artikel/Evaluasi Kepsek/Konsep Penilaian Kinerja Kepala Sekolah .

Suskacevic,M and S. Blake. 1999. Principal's Leadership and Student Achievement: 
An Examination of Theis TIMSS 1999. University of Texas at EL Paso, USA.

Velser, E. V., M. Ruderman and A. Phillips. 1999. Enhancing Self objectivity and Performance on-the-Job: The Developmental Impact of Feedback (Working Paper). Greensbord NC: Center for Creative Leadership.
Winarsunu,T. 2002. Statistik dalam Penelitian Psikologi \& Pendidikan. Malang: Universitas Muhammadiyah Malang.

Xaviery. 2004. Benarkah wajah sekolah ada pada kepala sekolah. Diunduh pada tanggal 8 Juli 2010 dari http://re. earchengines.com/xaviery.html 